Wiyadi, Amalina, Trisnawati, dan Sasongko/ 2017

\title{
PERSPEKTIF POSITIF PRAKTIK MANAJEMEN LABA: KAJIAN EMPIRIS PADA PERUSAHAAN MANUFAKTUR GO PUBLIK DI BURSA EFEK INDONESIA
}

\author{
Wiyadi $^{1}$ \\ * Fakultas Ekonomi dan Bisnis, Universitas Muhammadiyah Surakarta \\ *wiyadi@ums.ac.id ${ }^{1}$ \\ Nur Amalina ${ }^{2}$ \\ * Fakultas Ekonomi dan Bisnis, Universitas Muhammadiyah Surakarta \\ *amalinanur223@gmail.com ${ }^{2}$ \\ Rina Trisnawati ${ }^{3}$ \\ * Fakultas Ekonomi dan Bisnis, Universitas Muhammadiyah Surakarta \\ * rina.trisnawati@ums.ac.id ${ }^{3}$ \\ Noer Sasongko ${ }^{4}$ \\ * Fakultas Ekonomi dan Bisnis, Universitas Muhammadiyah Surakarta \\ *noer_sasongko@ums.ac.id ${ }^{4}$
}

\begin{abstract}
The earnings management practice has a positive and negative perspectives. This study aimed to analyze the effect of earnings management, corporate performance, quality audits, and Investment opportunity set to cost of equity companies are included in the Islamic index (JII) and conventional index (LQ-45). Measuring the earnings management used a short-term discretionary accruals (STDA) model. There were 461 companies (257 companies LQ-45 and 204 companies JII) taken by purposive sampling. Data was analyzed using multiple linear regression. Result of the data analysis showed that earnings management and company performance has no significantly effect on the cost of equity in both companies as well as JII and LQ-45. The quality of audit has significantly effect on the cost of equity in the JII companies, but had not significantly effect on the LQ-45 companies. And the investment opportunity set significantly effect on the cost of equity as well as in both of JII and LQ-45 companies. This indicates the earnings management in Indonesia tend to use a negative or opportunistic perspectives.
\end{abstract}

Keywords: earnings management, corporate performance, quality audits, investment opportunity set, cost of equity capital.

\section{Pendahuluan}

Dalam teori agensi mendiskripsikan hubungan antara prinsipal (pemilik) dengan agen (manajer). Hubungan kerja antara pemilik dengan manajer berbentuk kontrak kerja (Scott dalam Utami, 2005). Manajer dikontrak dan dipercaya oleh pemilik untuk menjalankan operasi perusahaan. Ia harus bertanggung jawab untuk mengoptimalkan keuntungan bagi pemilik dan dapat menarik investor baru. Sebagai imbalannya ia akan memperoleh kompensasi sesuai kontrak.

Para investor bersedia untuk menginves-tasikan modal mereka hanya pada perusahaan yang memiliki kinerja baik. Baik tidaknya kinerja perusahaan tercermin pada laporan keuangan yang dipublikasikan. Laporan keuangan digunakan sebagai penyalur informasi yang bermanfaat bagi perusahaan dan pemilik modal. Para investor cenderung lebih menyukai perusahaan yang mempubli-kasikan laporan keuangannya untuk memini-malisir resiko. Oleh sebab itu, manajer harus mampu menyajikan laporan keuangan perusahaan agar dapat menarik perhatian investor. Jika kinerja perusahaan baik, maka investor berharap memperoleh return atas investasi yang mereka lakukan tinggi. Tingkat return yang tinggi menyebabkan resiko atas investasi atau biaya modal ekuitas rendah.

Biaya modal ekuitas (cost of equity capital) adalah tingkat pengembalian yang harus dicapai perusahaan untuk memenuhi tingkat return yang diharapkan para pemegang saham (Bodie dalam Nurjanati, 2015). Jadi Biaya modal ekuitas adalah tingkat return yang diharapkan oleh investor (pemilik 
modal) atas investasi yang dilakukan atau sebagai rate yang digunakan investor dalam memprediksi arus kas pada periode mendatang. Semakin tinggi biaya modal ekuitas, maka semakin rendah risiko yang dihadapi investor.

Biaya modal ekuitas dapat diminimalisir melalui tindakan manajemen laba. Manaje-men laba adalah salah satu faktor yang dapat mempengaruhi biaya modal ekuitas. Menurut Scott (2009) dalam Migdad (2012) bahwa manajemen laba adalah sebuah kebijakan akuntansi yang dipilih manajer yang dapat mempengaruhi laba sehingga mencapai beberapa tujuan dalam pelaporan laba. Jadi manajemen laba dapat dipandang sebagai sebuah estimasi laba agar terhindar dari reaksi negatif para investor, serta dapat digunakan untuk melindungi diri dan perusahaan dalam mengantisipasi kejadian yang tidak terduga atas keuntungan dari pihak yang terlibat didalam kontrak.

Manajemen laba memiliki dua perspektif, yaitu: perspektif negatif (oportunistik), dan perspektif positif (efisien). Dalam artikel ini perspektif yang digunakan adalah perspektif positif. Sehingga manajemen laba dipandang sebagai upaya untuk memuaskan pemegang saham serta upaya memaksimalkan nilai perusahaan. Hal ini berarti bahwa tindakan manajemen laba menurunkan risiko persepsi investor atas ketidakpastian tingkat return dimasa mendatang. Maka melalui manajemen laba diharapkan mampu memperbaiki nilai perusahaan. Oleh sebab itu, manajer harus mampu menyediakan informasi yang menarik kepada para investor, sehingga berdampak pada peningkatan biaya modal ekuitas.

Manajemen laba menyebabkan banyak informasi yang harus diungkap oleh perusahaan. Konsekuensinya biaya yang dikeluarkan perusahaan untuk penyediaan informasi bagi publik (cost of equity capital) meningkat. Hasil penelitian Utami (2005) dan Fitriyani (2014) menyatakan bahwa manaje-men laba mempunyai pengaruh yang positif terhadap biaya modal ekuitas. Berarti semakin tinggi manajemen laba atau semakin mening-katmya akrual, maka semakin meningkatkan pula biaya modal ekuitas (cost of equity capital) yang dikeluarkan perusahaan.

Selain manajemen laba, bahwa variabel yang mempengaruhi biaya modal ekuitas antara lain: kinerja perusahaan, kualitas audit, Investment opportunity set $(I O S)$, ukuran perusahaan, pengungkapan sukarela, asimetri informasi, beta saham, dan sebagainya. Berdasarkan uraian diatas, maka tujuan dari penulisan artikel ini adalah menguji secara empiris pengaruh manajemen laba, kinerja perusahaan, kualitas audit, dan investment opportunity set terhadap biaya modal ekuitas.

\section{Kajian Pustaka dan Pengembangan Hipotesis} Biaya Modal Ekuitas (Cost of equity capital).

Istilah biaya modal ekuitas memiliki beberapa pengertian. Menurut Modigliani dan Miller (1958) biaya modal ekuitas adalah suatu biaya yang dikeluarkan guna membiayai pembelanjaan (source of financing). Sedang menurut Bodie dalam Nurjanati (2015) bahwa biaya ekuitas adalah tingkat pengembalian yang harus dicapai oleh perusahaan untuk memenuhi tingkat expected return para pemegang saham. Biaya modal ekuitas juga didefinisikan sebagai tingkat keuntungan yang diperoleh pemilik modal atas modal yang telah diserahkan pada perusahaan (Husnan, 1997). Berdasarkan beberapa pengertian diatas, maka dapat disimpulkan bahwa biaya modal ekuitas adalah tingkat return yang diharapkan atau rate yang digunakan oleh investor dalam memprediksi arus kas pada periode mendatang.

Modal ekuitas dapat diperoleh perusa-haan melalui dua cara, yaitu: melalui laba ditahan, dan dengan mengeluarkan saham baru (Brigham dan Weston, 1994). Dari sisi perusahaan, bahwa biaya modal ekuitas dipandang sebagai biaya yang akan ditanggung untuk memperoleh modal dari luar dan menggunakan modal tersebut (Ashidiqi, 2013). Menurut (Utami, 2005) biaya modal ekuitas dapat diukur dengan menggunakan: (1) Model penilaian partum-buhan konstant (Gordon Model); (2) Capital Asset Pricing Model (CAPM); dan (3) Model Ohlson.

Menurut Brigham dan Weston (1994), pentingnya biaya modal ekuitas adalah: (1) Untuk memaksimalkan nilai perusahaa, (2) Manajer keuangan memerlukan estimasi dari biaya modal ekuitas agar dapat mengambil keputusan yang tepat, (3) Berbagai macam keputusan lain yang harus diambil oleh manajer keuangan, perlu estimasi biaya modal ekuitas.

\section{Manajemen Laba}

Manajemen laba mencakup usaha pihak manajemen untuk memaksimumkan atau 
meminimumkan laba, serta perataan laba sesuai dengan keinginan manajer (Copeland, 1968 dalam Utami, 2005). Menurut Setiawati dan Saputro (2004) dalam Ifonie (2012) manajemen laba adalah campur tangan yang dilakukan oleh pihak manajemen dalam proses penyusunan laporan keuangan guna untuk mencapai laba tertentu yang bertujuan menguntungkan diri sediri atau perusahaan. Dari uraian diatas, bahwa manajemen laba adalah usaha yang dilakukan oleh manajemen dalam pembuatan laporan keuangan perusahaan untuk memaksimalkan atau meminimumkan laba sesuai dengan yang diinginkan.

Manajer dengan sengaja melakukan tindakan manajemen laba dengan pola manaikkan atau menurunkan laba pada laporan keuangan. Tindakan ini dilakukan untuk menarik investor agar mau menginvestasikan atau menanamkan modalnya kedalam perusahaan dengan harapan akan memperoleh return atas investasinya.

Menurut Scott (1997) dalam Poerbasari dan Sasongko (2012) bahwa ada dua pespektif dalam memahami manajemen laba. Pertama, Perspektif oportunistik: Manajemen laba sebagai perilaku yang oportunistik manajer, yang bertindak memaksimalkan utilitas dalam menghadapi kontrak kompensasi, kontrak utang, dan political costs (Opportunistic Earnings Management). Kedua Perspektif efisien: Manajemen laba dipandang dari perspektif efficient contracting, dimana manajer diberikan fleksibilitas untuk melindungi diri dan perusahaan dalam meminimalisir kejadian yang tidak diduga. Dalam perspektif ini Scott memandang bahwa manajer dapat mepengaruhi nilai pasar melalui manajemen laba dengan membuat perataan laba.

Manajemen laba dapat diukur dengan menggunakan manajemen laba akrual (short term accrual model dan long term accrual model), manajemen laba rill, dan manajemen laba terintegrasi. Merurut kusuma (2006) dalam Trisnawati dkk (2016) bahwa mana-jemen laba akrual memiliki karakteristik yang berbeda. Model short term accruals merupakan cara manajemen laba yang berkaitan dengan melalui aktiva dan hutang lancar, sedangkan model long term accruals merupakan cara manajemen laba yang berkaitan dengan aktiva tetap dan hutang jangka panjang. Dampak yang timbul dari penggunaan long term discretionary accrual lebih besar jika dibanding dengan Short term discretionary accrual. Sebab model long term mampu memberikan informasi yang lebih dibandingkan short term.

\section{Manajemen Laba dan Biaya Modal Ekuaitas}

Menurut Setiawati dan Saputro (2004) dalam Ifonie (2012) manajemen laba adalah campur tangan yang dilakukan oleh pihak manajemen dalam proses penyusunan laporan keuangan guna mencapai laba tertentu yang bertujuan menguntungkan diri sediri atau perusahaan. Manajemen laba juga didefi-nisikan sebagai kebijakan akuntansi yang dipilih manajer yang dapat mempengaruhi laba sehingga mencapai beberapa tujuan dalam pelaporan laba (Scott, 2009 dalam Migdad (2012).

Manajemen laba memerlukan banyak informasi yang harus diungkap oleh perusa-haan, sehingga menyebabkan meningkatnya biaya yang harus dikeluarkan oleh perusahaan untuk menyediakan informasi bagi publik (biaya modal ekuitas). Selanjutnya Ashidiqi (2013) menyatakan bahwa biaya modal ekuitas adalah rate yang diharapkan investor untuk menilai-tunaikan arus kas yang diharapkan dapat diterima di masa mendatang.

Tindakan manajemen laba dilakukan atas dasar keinginan manajer untuk mempengaruhi persepsi investor atas risiko perusahaan. Menurut Stowly dan Berton (2000) dalam Utami (2005) risiko dibagi menjadi dua, yaitu: risiko yang dihubungkan dengan imbal hasil yang diukur menggunakan earning per share (EPS), dan risiko yang dihubungkan dengan stuktur keuangan perusahaan yang diukur menggunakan debt equity ratio (DER). Dari pernyataan diatas, maka tujuan dari manajemen laba adalah mengurangi risiko.

Penelitian Utami (2005), Fitriyani (2014) menyatakan bahwa manjemen laba berpenga-ruh positif dan signifikan terhadap biaya modal ekuitas. Berarti semakin tinggi mana-jemen laba maka semakin tinggi biaya modal ekuitas, dimana biaya modal ekuitas diukur dengan menggunakan model Ohlson.

Berdasarkan penjelasan ini dapat dirumuskan hipotesis sebagai berikut:

$\mathrm{H}_{1}$ : Manajemen laba berpengaruh terhadap biaya modal ekuitas.

\section{Kinerja Perusahaan dan Biaya Modal Ekuitas}

Kinerja perusahaan mencerminkan kemampuan sebuah perusahaan yang dapat mencapai tujuan yang telah ditetapkan (Devani dan Setiawarnan, 2015). 
Untuk mengetahui apakah kinerja perusahaan baik ataukah tidak, maka diperlukan adanya evaluasi. Evaluasi kinerja perusahaan dilakukan untuk menjamin keberhasilan dalam pencapaian tujuan. Salah satu pengukuran kinerja perusahaan adalah menganalisis laporan keuangan dengan menggunakan rasio-rasio keuangannya (Pratiwi dan Pratama, 2012).

Jenis rasio keuangan yang digunakan untuk mengukur kinerja perusahaan, antara lain: (1) Rasio Likuiditas (Current Ratio, Quick Ratio, Net Working Capital, Defensive Interval Ratio); (2) Rasio Solvabilitas (Debt To Asset Ratio, Debt To Equity Ratio, Equity Multiplier, Interest Coverage); (3) Rasio Profitabilitas (Gross Profit Margin, Net Profit Margin, Return On Asset, Return On Equity, dan Earning Per Share Ratio); (4) Rasio Aktivitas (Receivable Turnover, Inventory Turnover, dan Receivable Turnover In Days).

Billet dan Ryngaert (1997) menyatakan bahwa kinerja perusahaan dapat mengubah biaya modal ekuitas. Pemegang saham menggunakan indikator kinerja untuk menentukan biaya modal ekuitas (Ely, 1995). Kinerja perusahaan yang baik dapat menurunkan biaya ekuitas, karena semakin baik kinerja perusahaan akan semakin rendah risiko yang dihadapi pemegang saham. Rehman dan Zaman (2011) juga menyatakan bahwa tingginya kinerja perusahaan dapat menurunkan biaya modal ekuitas. Jadi perusahaan yang memiliki kinerja tinggi risiko yang dihadapi rendah, sehingga dapat menurunkan biaya modal ekuitas.

Penelitian mengenai pengaruh kinerja perusahaan terhadap biaya modal ekuitas telah dilakukan oleh Esmaeili dan Sharifabadi (2015) di Bursa Efek Teheran. Hasil peneliti-annya menyatakan bahwa semakin tinggi kinerja perusahaan maka biaya modal ekuitas semakin rendah. Sehingga hipotesis yang dirumuskan adalah sebagai berikut:

$\mathrm{H}_{2}$ : Kinerja Perusahaan berpengaruh terhadap biaya ekuitas.

\section{Kualitas Audit dan Biaya Modal Ekuaitas}

Kualitas audit merupakan dasar bagi auditor untuk mendeteksi dan melaporkan salah saji material (De Angelo, 1981). Dalam mengaudit, seorang auditor harus berpedo-man pada standar pemeriksaan dan kode etik akuntan publik yang relevan. Seorang auditor harus berkompeten dan independen dalam melakukan tugas audit laporan keuangan (Kirana,
2013). Auditor yang berkompeten adalah auditor yang memiliki kemampuan teknologi, memahami dan melaksanakan prosedur audit secara benar. Sedangkan auditor yang independen adalah auditor yang ketika menemukan salah saji material langsung melaporkan kekeliruan tersebut.

Kualitas audit dikatakan baik jika mampu memberikan informasi yang bermanfaat bagi pengguna dalam pengambilan keputusan. Menurut Hajiha dan Shobani (2012) kualitas audit adalah kemungkinan auditor yang akan menemukan dan melaporkan salah saji material dalam suatu laporan keuangan. Standar Profesional Akuntan Publik (SPAP) menyatakan bahwa sebuah audit yang dilakukan auditor dikatakan berkualitas, jika memenuhi standar pengauditan yang mencakup: kualitas professional, auditor independen, pertimbangan yang digunakan, dan penyusunan laporan audit. Jadi kualitas audit adalah berbagai kemungkinan auditor ketika melakukan audit laporan keuangan klien dapat menemukan pelanggaran yang terjadi dalam sistem akuntansi klien dan melaporkannya dalam laporan keuangan auditan.

Salah satu ukuran dari kualitas audit adalah ukuran Kantor Akuntan Publik (KAP). Ukuran KAP yang besar atau KAP Big Four akan memberikan informasi yang lebih baik, sehingga informasi yang berkualitas ini dapat menurunkan cost of equity capital (Merto (1987), Leuz dan Verrachia (2005), Botosan et al (2004), dan Francis et al (2004) dalam Suparno (2013). Namun dalam kasus Enron/Andersen terjadi pandangan dari para peneliti yang menyatakan bahwa kualitas audit yang tinggi belum tentu memiliki ukuran KAP yang besar (Suparno, 2013).

Hasil penelitian Dong Yu (2007) menyatakan bahwa ukuran KAP Big Four memberikan kualitas audit yang lebih tinggi dibandingkan ukuran KAP Non Big Four. DeAnglo (1981) juga memberikan bukti bahwa auditor yang berukuran Big Four memberikan kualitas audit yang lebih baik dibandingkan dengan auditor yang berukuran Non Big Four, dimana auditor Big Four lebih memiliki keberanian lebih besar untuk menghadapi risiko dibandingkan auditor Non Big Four.

Hasil penelitian Fernando et al (2008) memberikan bukti bahwa ukuran perusahaan dan kualitas audit berpengaruh terhadap cost of equity capital. Hasil ini juga didukung oleh penelitian Setiawan dan Daljono (2014) serta Hajiha et al (2012) 
yang memberikan bukti bahwa kualitas audit yang baik dapat menurunkan cost of equity capital. Namun hasil penelitian Kirana (2013) menyatakan bahwa Ukuran KAP tidak berpengaruh signifikan cost of equity capital. Sehingga hipotesis yang dirumuskan peneliti adalah sebagai berikut:

$\mathrm{H}_{3}$ : Kualitas Audit berpengaruh terhadap biaya ekuitas.

\section{Investment opportunity set dan Biaya Modal Ekuaitas}

Investment opportunity set (IOS) adalah kombinasi yang dimiliki antara aset yang dimiliki perusahaan dengan pilihan investasi dimasa mendatang (Myers, 1977). Nilai perusahan merupakan salah satu proyeksi dari IOS yang besarnnya bergantung pada pengeluaran yang dilakukan perusahaan di masa mendatang (Gaver dan Gaver, 1993).

Nilai perusahaan juga merupakan hasil dari pilihan investasi yang digunakan di masa mendatang. Pilihan investasi adalah suatu kesempatan bagi perusahaan untuk berkembang. Namun tidak semua perusahaan dapat melakukan kesempatan investasi di masa mendatang, sehingga perusahaan yang tidak dapat melakukan kesempatan investasi akan mengalami pengeluaran yang lebih tinggi dibandingkan nilai kesempatan yang hilang. Kemampuan perusahaan yang dapat melakukan kesempatan investasi ini bersifat tidak dapat diobservasi, maka IOS memerlu-kan suatu proksi yang dapat dihubungkan dengan variabel lain dalam profitabilitas (Norpratiwi, 2004).

Pilihan investasi adalah kesempatan perusahan untuk berkembang. Perusahaan yang memiliki tingkat kesempatan partum-buhan potensial tinggi memiliki kecende-rungan untuk menghasilkan arus kas yang tinggi di masa mendatang dan kapitalisasi pasar yang tinggi sehingga memungkinkan perusahaan untuk memiliki biaya ekuitas yang rendah (Hermuningsih, 2012). Jadi tingkat kesempatan pertumbuhan perusahaan mempunyai hubungan yang negatif dengan biaya modal ekuitas. Berarti semakin tinggi tingkat pertumbuhan perusahaan, maka semakin rendah biaya modal ekuitas.

Penelitian mengenai Investment Opportunity Set terhadap biaya modal ekuitas telah dilakukan oleh Hermuningsih (2012) yang memberikan hasil bahwa Investment Opportunity Set berpengaruh negatif terhadap Cost of equity capital. Berarti bahwa semakin tinggi Investment opportunity set, maka semakin rendah Cost of equity capital. Sehingga dapat dirumuskan hipotesis sebagai berikut:

$\mathrm{H}_{4}$ : Investment opportunity set berpenga-ruh terhadap biaya modal ekuitas.

\section{Metode Penelitian \\ Populasi dan Sampel}

Populasi penelitian ini adalah seluruh perusahaan go publik di Bursa Efek Indonesia selama kurun waktu 2004-2015. Teknik pengambilan sampel dilakukan secara porposive sampling dengan kriteria: (1) Perusahaan yang terdaftar di Jakarta Islamic Index (JII) dan LQ-45, (2) Perusahaan manufaktur, (3) Perusahaan yang mempubli-kasikan laporan keuangan per 31 Desember selama kurun waktu 2004-2015 secara berturut-turut, (4) Perusahaan memiliki data laporan keuangan yang dipublikasikan secara lengkap.

\section{Definisi Operasional Variabel}

Variabel yang digunakan dalam penelitian ini ada 2, yaitu: variable dependen dan variable independen.

\section{Variabel dependen}

Variabel dependen dalam penelitian ini adalah biaya ekuitas. Biaya ekuitas merupakan tingkat pengembalian yang harus dicapai oleh perusahaan untuk memenuhi tingkat pengembalian harapan (expected return) para pemegang saham (Bodie, 2008 dalam Nurjanati, 2015). Perhitungan biaya ekuitas dalam penelitian ini menggunakan model Ohlson (1995), perhitungan ini juga pernah dilakukan oleh Utami (2005), yaitu:

\section{Definisi Operasional Variabel}

Variabel yang digunakan dalam penelitian ini ada 2, yaitu: variable dependen dan variable independen.

\section{Variabel dependen}

Variabel dependen dalam penelitian ini adalah biaya ekuitas. Biaya ekuitas merupa-kan tingkat pengembalian yang harus dicapai oleh perusahaan untuk memenuhi tingkat pengembalian harapan (expected return) para pemegang saham (Bodie, 2008 dalam Nurjanti, 2015). Perhitungan biaya ekuitas dalam penelitian ini menggunakan model Ohlson (1995), perhitungan ini juga pernah dilakukan oleh Utami (2005), yaitu: 


$$
r=\frac{\left(B_{t}+X_{t+1}-P_{t}\right)}{P_{t}}
$$

Keterangan:

R : biaya modal ekuitas

$\mathrm{P}_{\mathrm{t}}$ : harga saham periode $\mathrm{t}$

$\mathrm{B}_{\mathrm{t}}$ : nilai buku per lembar saham periode $\mathrm{t}$

$\mathrm{X}_{\mathrm{t}-1}$ : laba per lembar saham periode $\mathrm{t}+1$

Rumus diatas diperoleh dari hasil penyederhanaan dari:

$$
P_{t}=y_{t}+\sum_{\tau=1}^{T}(1+r)^{-\tau} E_{t}\left\{x_{\tau+1}-(r) y_{\tau+t-1}\right\}
$$

\section{Variabel independen}

Variabel independen dalam penelitian ini ada 4 variabel, yaitu: manajemen laba, kinerja perusahaan, kualitas audit, dan Investment opportunity set.

\section{Manajemen laba}

Manajemen laba adalah upaya yang dilakukan oleh manajemen dalam pembuatan laporan keuangan perusahaan untuk menaikkan atau menurunkan angka laba sesuai dengan yang diinginkan. Perhitungan manajemen laba dalam penelitian ini menggu-nakan Short Term Discretionary Accruals (STDA), sebagaimana pernah dilakukan oleh Rina dkk (2015), serta Poerbasari dkk (2012), yaitu:

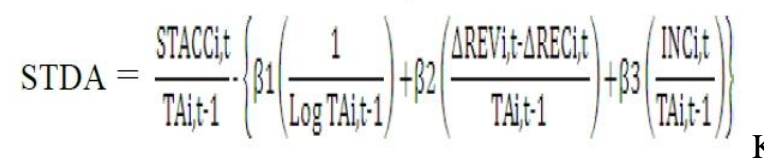

eterangan:

STDA : Short Term Discretionary Accruals

STACC : Short-term Accruals perusahaan i

periode $\mathrm{t}$

$\mathrm{TA}_{\mathrm{i}, \mathrm{t}-1}$ : total aktiva perusahaan i periode $\mathrm{t}-1$

$\mathrm{REV}_{\mathrm{i}, \mathrm{t}}:$ : Revenue perusahaan i periode $\mathrm{t}$

$\mathrm{REC}_{\mathrm{i}, \mathrm{t}} \quad$ : Receivable perusahaan i periode $\mathrm{t}$

$\mathrm{INC}_{\mathrm{i}, \mathrm{t}} \quad$ : Laba bersih perusahaan i periode $\mathrm{t}$

Kinerja Perusahaan

Kinerja merupakan sejauhmana kemam-puan perusahaan dapat mencapai tujuan perusahaan yang telah ditetapkan (Devani dan Setiawarnan, 2015). Pengukuran kinerja perusahaan dalam penelitian ini menggunakan Return On Asset (ROA), pengukuran ini juga pernah dilakukan oleh Rehman dan Zaman (2010), Pratiwi dan Pratama (2012), dan Jati (2009), yaitu:

$$
\text { ROA }=\frac{\text { Laba Bersih Setelah pajak }}{\text { Total Asset }} \times 100 \%
$$

\section{Kualitas Audit}

Kualitas audit adalah kemungkinan auditor yang akan menemukan serta melaporkan salah saji material dalam suatu laporan keuangan (Hajiha dan Shobani. Proksi yang digunakan untuk variabel kualitas audit adalah Ukuran Kantor Akuntan Publik (KAP). Ukuran KAP merupakan besar atau kecilnya suatu KAP. De Angelo (1981) dalam Setiawan dan Daljono (2014) menyatakan bahwa auditor berukuran besar (Big Four) memberikan kualitas yang lebih tinggi dibandingkan auditor berukuran kecil (Non Big Four). Ukuran KAP menggunakan pengukuran dari skala KAP. Dimana skala KAP ini dibagi menjadi 2, yaitu KAP yang berafiliasi dengan Big Four dan KAP yang tidak berafiliasi dengan Big Four (Non Big Four). Variabel ukuran KAP ini diukur dengan menggunakan variabel dummy, pengukuran ini pernah digunakan oleh Fernando et al (2008), dan Kirana (2013). Dimana perusahaan yang diaudit oleh Kantor Akuntan Publik (KAP) yang berafiliasi dengan Big Four akan diberi angka 1, sedangkan perusahaan yang diaudit oleh KAP yang tidak berafiliasi dengan Big Four (Non Big Four) diberi angka 0.

\section{Investment opportunity set}

Investment opportunity set (IOS) adalah kombinasi yang dimiliki antara asset in place perusahaan (asset yang dimiliki) dengan investment options (pilihan investasi) dimasa mendatang (Myers, 1977). Kemampuan perusahaan yang dapat melakukan kesem-patan investasi ini bersifat tidak dapat diobservasi, maka IOS memerlukan suatu proksi. Proksi IOS yang digunakan dalam penelitian ini adalah Price Earning Ratio (PER), perhitungan ini juga pernah dilakukan oleh Hermuningsih (2012), yaitu:

\section{$\mathrm{PER}=\frac{\text { Harga saham }}{\text { laba per lembar saham }}$}

\section{Pengujian Hipotesis}

Penelitian ini bertujuan untuk menguji pengaruh manajemen laba, kinerja perusahaan, kualitas audit, dan investment opportunity set terhadap biaya modal ekuitas. Data yang digunakan adalah data 
sekunder yang berupa laporan keuangan perusahaan yang terdaftar di Bura Efek Indonesia dan dipublikasikan per 31 Desember selama kurun waktu 2004-2015. Sumber dari Indonesian Capital Market Directory melalui www.idx.go.id.

Uji hipotesis dilakukan dengan regresi linier berganda. Regresi linier berganda digunakan untuk mengukur kekuatan hubungan antara dua variabel atau lebih, serta menunjukkan arah hubungan antara variabel dependen dengan variabel independen (Ghozali, 2011). Persamaan model regresi dalam penelitian ini adalah:

$Y=\beta_{0}+\beta_{1} X_{1}+\beta_{2} X_{2}+\beta_{3} X_{3}+\beta_{4} X_{4}+e$

Keterangan:

$\mathrm{Y} \quad=$ biaya ekuitas

$\beta_{0} \quad=$ konstanta

$\beta_{1,2,3}=$ koefisien regresi setiap variabel

$\mathrm{X}_{1} \quad=$ manajemen laba

$\mathrm{X}_{2} \quad=$ kinerja perusahaan

$\mathrm{X}_{3} \quad=$ kualitas audit

$\mathrm{X}_{4} \quad=$ Investment opportunity set

$\mathrm{e} \quad=$ faktor Pengganggu

\section{Hasil dan Pembahasan Deskripsi Sampel}

Hasil seleksi sampel menggunakan teknik purposive sampling. Jumlah sampel yang digunakan dalam penelitian ini yaitu, untuk JII berjumlah 204 dan LQ-45 berjumlah 257. Secara rinci dapat dilihat pada Tabel 1 (terlampir).

\section{Deskriptif Statistik}

Deskriptif tatistik dimaksudkan untuk memberikan gambaran data yang dianalisis dilihat dari minimum, maksimum, rata-rata (mean). Tabel 2 (terlampir) adalah hasil deskriptif statatistik seluruh variabel yang diteliti.

Berdasarkan tabel 2, hasil perhitungan biaya modal ekuitas pada perusahaan di indeks JII diperoleh nilai rata-rata sebesar $-0,94301$. Nilai terendah adalah 1,07915, dan nilai tertinggi $-0,79761$. Sedangkan pada perusahaan di indeks LQ-45 diperoleh nilai rata-rata sebesar $-0,94029$. Nilai terendah $-1,14042$, dan nilai tertinggi adalah $-0,80336$. Dengan hasil rata-rata biaya ekuitas -0,94301 dan -0,94029, ini menunjukkan bahwa tingkat ekspektasi investor terhadap return yang akan diterima rendah.
Nilai rata-rata manajemen laba perusa-haan di indeks JII sebesar $-0,10825$. Nilai terendah sebesar 1,87875, dan nilai tertinggi sebesar 0,99946 . Sedangkan pada perusahaan di indeks LQ-45 diperoleh nilai rata-rata sebesar $-0,40372$. Nilai terendah adalah 1,05425 , dan nilai tertinggi adalah $-0,04329$. Dengan nilai rata-rata $-0,10825$ dan $-0,40372$, ini menunjukkan bahwa manajer melakukan manajemen laba dengan cara menurunkan angka laba.

Hasil perhitungan kinerja perusahaan pada perusahaan di indeks JII diperoleh nilai rata-rata sebesar 0,14193 . Nilai terendah sebesar $-0,04561$, dan nilai tertinggi adalah 0,71508. Sedangkan pada perusahaan di indeks LQ-45 diperoleh nilai rata-rata sebesar 0,23367. Nilai terendah adalah -0,09594, dan nilai tertinggi adalah 29,31967. Dengan nilai rata-rata kinerja perusahaan 0,14193 dan 0,23367 , ini menunjukkan bahwa perusahaan mampu mengelola nilai asetnya secara baik.

Hasil perhitungan kualitas audit pada perusahaan di indeks JII diperoleh nilai rata-rata sebesar 0,8333 . Nilai terendah adalah 0 , dan nilai adalah 1. Sedangkan pada perusahaan di indeks LQ-45 diperoleh nilai rata-rata sebesar 0,8054 . Dengan nilai rata-rata kualitas auditor 0,8333 dan 0,8054 , ini menunjukkan bahwa perusahaan lebih banyak menggunakan auditor yang berkualitas atau Big Four.

Hasil perhitungan IOS pada perusahaan di indeks JII diperoleh nilai rata-rata sebesar 22,3703. Nilai terendah adalah $-42,61$, dan nilai tertinggi adalah 336,96. Sedangkan pada perusahaan di indeks LQ-45 diperoleh nilai rata-rata sebesar 19,4295. Nilai terendah adalah $-42,61$, dan nilai tertinggi adalah 255,12 . Dengan nilai rata-rata Investment opportunity set $2237,03 \%$ dan 1942,95\%, ini menunjukkan bahwa perusahaan memiliki peluang pertumbuhan yang baik karena memiliki nilai diatas $100 \%$.

\section{Uji Asumsi klasik}

\section{Uji Normalitas}

Uji normalitas digunakan untuk mengidentifikasi apakah suatu model regresi berdistribusi normal atau tidak. Metode yang digunakan adalah uji KS (Kolmogorov-Smirnov). Dari hasil uji normalitas perusahaan yang tergabung di indeks JII dan LQ-45 diperoleh nilai Asymp.Sig (2tailed) lebih besar dari 0.05 (terlampir), berarti data berdistribusi normal. 


\section{Uji Multikolinieritas}

Uji multikolineritas digunakan untuk mengidentifikasi apakah variabel independen satu dan yang lainnya dapat dikatakan sebagai kombinasi linier dari variabel independen yang lain (Murni, 2002). Dalam penelitian ini, uji multikolinearitas yang digunakaan adalah dengan melihat nilai VIF (variance inflation factor) dan Tolerance.

Dari hasil uji multikoliniearitas perusa-haan yang tergabung di indeks JII dan LQ-45, semua variabel memiliki nilai tolerance mendekati 1 dan nilai VIF kurang dari 10, sehingga dapat disimpulkan bahwa pada model regresi ini tidak terjadi multikolinieritas.

\section{Uji Heteroskedastisitas}

Uji heteroskedastisitas digunakan untuk mengidentifikasi apakah pada model regresi terjadi ketidaksamaan variance dari residual dari satu pengamatan ke pengamatan yang lain (Ghozali, 2011). Dalam penelitian ini, uji heteroskedastisitas yang digunakaan adalah uji white. Model regresi dikatakan tidak mengalami heteroskedastisitas ketika $\mathrm{X}_{\text {hitung }}^{2}<$ $\mathrm{X}_{\text {tabel }}^{2}$. Dari hasil uji heteroskedastisitas perusahaan di indeks JII dan LQ-45 (terlam-pir) bahwa $\mathrm{X}_{\text {hitung }}^{2}<$ $\mathrm{X}_{\text {tabel }}^{2}$ maka dapat disimpulkan bahwa pada model regresi ini tidak terjadi heteroskedastisitas.

\section{Uji Autokorelasi}

Uji autokorelasi digunakan untuk mengidentifikasi apakah dalam model regresi linear ada korelasi antara kesalahan pengganggu pada periode $t$ dengan kesalahan penganggu pada periode $\mathrm{t}-1$ (sebelumnya) (Ghozali, 2011). Dalam penelitian ini, uji autokorelasi yang digunakaan adalah uji DW (Durbin Watson). Dari hasil uji autokorelasi perusahaan yang tergabung di indeks JII dan LQ-45 (terlampir) diperoleh nilai DW (Durbin Watson) antara 1,5 sampai 2,5, sehingga dapat disimpulkan bahwa tidak terjadi autokorelasi dalam model regresi.

\section{Analisis Regresi Linier Berganda}

Analisis regresi linier berganda digunakan untuk mwngukur kekuatan hubungan antara dua variabel atau lebih, serta menunjukkan arah hubungan antara variabel dependen dengan variabel independen (Ghozali, 2011). Hasil perhitungan yang diperoleh dapat dilihat pada Tabel 3 (terlampir).
Berdasarkan hasil pengujian regresi linier perusahaan yang tergabung di indeks JII pada tabel 3, maka dapat dibuat persamaan sebagai berikut:

$Y_{1}=-0,910+0,001 X_{1.1}-0,023 X_{1.2}-0,026 X_{1.3}-$ $0,0003 \mathrm{X}_{1.4}+\mathrm{e}$

$Y_{2}=-0,927+0,0002 X_{2.1}-0,002 X_{2.2}-0,002 X_{2.3}-$ $0,0007 \mathrm{X}_{2.4}+\mathrm{e}$

Berdasarkan persamaan regresi linear berganda diatas maka dapat diintrepetasikan sebagai berikut:

a. Koefisien regresi manajemen laba pada perusahaan indeks JII (X1.1) sebesar 0,001 dan manajemen laba pada perusahaan indeks LQ-45 (X2.1) sebesar 0,0002 berarti bahwa semakin tinggi manajemen laba semakin tinggi biaya modal ekuitas.

b. Koefisien regresi kinerja perusahaan pada indeks JII (X1.2) sebesar -0,023 dan kinerja perusahaan pada perusahaan indeks LQ-45 (X2.2) sebesar 0,002 berarti semakin tinggi kinerja perusahaan maka akan semakin rendah biaya modal ekuitas.

c. Koefisien regresi kualitas auditor pada perusahaan indeks JII (X1.3) sebesar -0,026 dan kualitas auditor pada perusahaan indeks LQ-45 (X2.2) sebesar -0,002 berarti semakin tinggi kualitas auditor maka semakin rendah biaya modal ekuitas.

d. Koefisien regresi Investment Opportunity Set pada perusahaan indeks JII (X1.4) sebesar 0,0003 dan Investment opportunity set pada perusahaan indeks LQ-45 (X2.4) sebesar -0,0007 berarti semakin tinggi Investment opportunity set maka semakin rendah biaya modal ekuitas.

\section{Uji Ketepatan Model (Uji F dan $\mathbf{R}^{2}$ )}

Hasil regresi diperoleh nilai $F_{\text {hitung }}$ pada indek JII sebesar 7,940 dengan tingkat signifikansi 0,000 dan pada indeks LQ-45 sebesar 9,435 dengan tingkat signifikansi 0,000. Karena tingkat signifikansi kurang dari 0,05 atau $0,000<0,05$ berati model yang digunakan adalah tepat atau fit.

Nilai koefisien determinasi (R2) perusahaan yang tergabung di indeks JII diperoleh sebesar 0,138 $(13,8 \%)$ dan perusahaan yang tergabung di indeks LQ45 sebesr 0,130 (13\%). Yang berarti bahwa kontribusi variabel independen yang terdiri dari manajemen laba, kinerja perusahaan, kualitas audit dan Investment opportunity set pada indeks JII mampu menjelaskan variasi perubahan variabel dependen (biaya modal 
ekuitas) sebesar $13,8 \%$, sedangkan sisanya sebesar $86,2 \%$ dijelaskan oleh variabel lain diluar model.

Kontribusi variabel independen yang terdiri dari manajemen laba, kinerja perusahaan, kualitas audit dan Investment opportunity set pada indeks LQ45 mampu menjelaskan variasi perubahan variabel dependen (biaya modal ekuitas) sebesar 13\%, sedangkan sisanya sebesar $87 \%$ dijelaskan oleh variabel lain diluar model.

\section{Uji Ketepatan Parameter Penduga (Uji t)}

a. Manajemen laba pada perusahaan di indeks JII memiliki nilai $t_{\text {hitung }}$ sebesar 0,105 dengan tingkat signifikansi 0,918 dan pada indeks LQ-45 memiliki nilai $t_{\text {hitung }}$ sebesar 0,011 dengan tingkat signifikansi 0,991. Karena tingkat signi-fikansi masing-masing lebih besar 0,05 maka $\mathrm{H}_{0}$ diterima. Berarti manajemen laba tidak berpengaruh terhadap biaya modal ekuitas baik pada indeks JII maupun indeks LQ-45. Ini disebabkan oleh adanya antisipasi manajemen laba yang dilakukan oleh para investor dalam mengambil keputusan atas investasinya.

b. Kinerja perusahaan pada perusahaan di indeks JII memiliki nilai $t_{\text {hitung }}$ sebesar $-0,843$ dengan tingkat signifikansi 0,400 dan pada indeks LQ-45 memiliki nilai $t_{\text {hitung }}$ sebesar $-1,195$ dengan tingkat signifikansi 0,233 . Karena tingkat signifikansi masing-masing indeks lebih besar dari 0,05 maka $\mathrm{H}_{0}$ diterima. Berarti kinerja perusahaan tidak berpengaruh terhadap biaya modal ekuitas baik pada perusahaan indeks JII maupun pada indeks LQ-45. Ini terjadi karena para investor telah yakin bahwa kinerja perusahaan baik. Sehingga investor tidak begitu memperhatikan kinerja perusa-haan. Selain itu perusahaan di indeks JII maupun indeks LQ-45 memiliki risiko yang terbatas dan kualitas yang lebih baik karena ada pembatasan tingkat leverage (Sinarti dan Na'im, 2010).

c. Kualitas auditor pada perusahaaan di indeks JII memiliki nilai $t_{\text {hitung }}$ sebesar $-3,030$ dengan tingkat signifikansi 0,003 dan pada indeks LQ-45 memiliki nilai $t_{\text {hitung }}$ sebesar 0,264 dengan tingkat signifikansi 0,792. Karena pada perusa-haan di indeks JII memiliki tingkat signifikansi kurang dari 0,05 maka H0 ditolak, yang artinya bahwa kualitas auditor berpengaruh terhadap biaya modal ekuitas. Sedangkan pada indeks LQ-45 memiliki tingkat signifikansi lebih dari 0,05 maka $\mathrm{H}_{0}$ diterima, yang artinya bahwa kualitas audit tidak berpengaruh terhadap biaya ekuitas. Penyebabnya para investor tidak memperhatikan siapa auditor yang digunakan oleh perusahaan, dimana mereka yakin bahwa auditor yang digunakan pada perusahaan di indeks LQ-45 adalah auditor yang berkualitas. Sehingga para investor tidak mengguna-kan kualitas audit dalam pengambilan keputusan.

d. Investment opportunity set pada indeks JII memiliki nilai $t_{\text {hitung }}$ sebesar $-4,460$ dengan tingkat signifikansi 0,000 dan pada indeks LQ-45 memiliki nilai $t_{\text {hitung }}$ sebesar $-5,997$ dengan tingkat signifikansi 0,000 . Karena keduanya memiliki tingkat signifikansi lebih besar dari 0,05 maka $\mathrm{H}_{0}$ ditolak. Berarti investment opportunity set berpengaruh terhadap biaya modal ekuitas baik pada perusahaan yang tergabung di indeks JII maupun indeks LQ-45.

\section{Pembahasan}

\section{a. Pengaruh manajemen laba terhadap biaya ekuitas}

Brdasarkan hasil pengujian manajemen laba tidak bepengaruh terhadap biaya ekuitas. Tidak berpengaruhnya manajemen laba terhadap biaya modal ekuitas disebabkan oleh adanya antisipasi manajemen laba yang dilakukan oleh para investor dalam mengambil keputusan atas investasinya. Hasil penelitian Leuz et al dalam Utami (2005) menyatakan jika dibandingkan dengan negara ASEAN, Indonesia merupakan negara yang memiliki tingkat overstate earnigs dalam manajemen laba paling besar. Selain itu, rata-rata perusahaan di Indonesia juga cenderung melakukan manajemen laba, hasil tersebut diperoleh dari survei yang dilakukan oleh Price Waterhouse Coopers (Eccles et al, 2006 dalam Purwanto 2012).

Hasil temuan ini tidak konsisten dengan hasil penelitian Utami (2005) dan Fitriyani (2014) yang menyatakan bahwa manajemen laba berpengaruh terhadap biaya ekuitas. Namun manajemen laba dapat dipandang sebagai peramalan laba agar terhindar dari reaksi negatif para investor serta dapat digunakan untuk melindungi diri. Ini menunjukkan bahwa praktik manajemen laba yang dilakukan perusahaan tidak disadari oleh investor.

Selain itu manajer melakukan tindakan opportinistik yang mementingkan kepenting-an pribadinya. Sehingga hasil penelitian ini konsisten 
dengan penelitian Ifonie (2012), Perwira dan Darsono (2015), dan Ashidiqi (2013) yang menyatakan bahwa manajemen laba tidak berpengaruh terhadap biaya ekuitas.

\section{b. Pengaruh kinerja perusahaan terhadap biaya ekuitas}

Berdasarkan hasil pengujian bahwa kinerja perusahaan tidak bepengaruh terhadap biaya modal ekuitas. Hasil ini tidak konsisten dengan hasil penelitian Esmaeili dan Sharifabadi (2015) yang menyatakan bahwa kinerja perusahaan berpengaruh terhadap biaya ekuitas.

Kinerja perusahaan tidak berpengaruh terhadap biaya ekuitas karena para investor tidak memperhatikan kinerja perusahaan dalam pengambilan keputusan baik pada perusahaan indeks JII maupun indeks LQ-45. Para investor percaya bahwa kinerja perusahaan perusahaan baik karena mereka merupakan perusahaan-perusahaan yang likuid. Sehingga investor menggunakan faktor lain dalam pengambilan keputusan.

\section{c. Pengaruh kualitas audit terhadap biaya ekuitas}

Hasil pengujian membuktikan bahwa kualitas audit berpengaruh terhadap biaya ekuitas pada perusahaan indeks JII. Sehingga jika perusahaan menggunakan auditor yang berkualitas (Bigfour) maka diikuti oleh penurunan biaya ekuitas. Auditor yang berkualitas (Bigfour) memberikan informasi yang lebih baik. Karena mereka memiliki keberanian yang lebih besar untuk menghadapi risiko. Selain itu, mereka lebih mengutamakan service yang terbaik dalam mengaudit, sehingga dapat menimbulkan kepercayaan investor. Hasil penelitian ini konsisten dengan (Merto (1987), Leuz dan Verrachia (2005), Botosan et al (2004), dan Francis et al (2004) dalam Suparno (2013), dan Fernando et al (2008).

Sedangkan pada perusahaan di indeks LQ-45 menyatakan bahwa kinerja perusahaan tidak bepengaruh terhadap biaya modal ekuitas. Karena dalam pengambilan keputus-an para investor tidak memperhatikan auditor yang digunakan oleh perusahaan. Hasil penelitian ini konsisten dengan penelitian Kirana (2013) bahwa para investor tidak memperhatikan auditor yang digunakan oleh perusahaan.

\section{d. Pengaruh Investment opportunity set terhadap biaya ekuitas}

Laporan keuangan harus memberikan informasi yang jelas dan lengkap mengenai kegiatan perusahaan. Informasi yang diungkapkan harus berguna dan tidak membingungkan bagi pemakai laporan keuangan dalam pengambilan keputusan (Hermuningsih, 2012).

Berdasarkan hasil pengujian investment opportunity set berpengaruh terhadap biaya modal ekuitas baik pada perusahaan di indeks JII maupun indeks LQ-45. Karena Investment opportunity set (IOS) memiliki pengaruh negatif terhadap biaya modal ekuitas, berarti semakin tinggi IOS maka semakin rendah biaya modal ekuitas. Hasil penelitian ini konsisten dengan hasil penelitian Hermuningsih (2012) yang menyatakan bahwa semakin tinggi IOS maka semakin rendah biaya ekuitas.

\section{Simpulan}

a. Praktik manajemen laba pada perusahaan di indeks JII maupun LQ-45 dilakukan dengan menggunakan pola mengurangi angka laba.

b. Manajemen laba tidak berpengaruh terhadap biaya modal ekuitas pada perusahaan di indeks JII dan LQ 45. Sehingga hipotesis yang menyatakan bahwa manajemen laba berpengaruh terhadap biaya modal ekuitas pada perusahaan di indeks JII dan LQ 45 tidak terbukti kebenarannya.

c. Kinerja perusahaan tidak berpengaruh terhadap biaya ekuitas pada perusa-haan di indeks JII dan LQ 45. Sehingga hipotesis yang menyatakan bahwa kinerja perusahaan berpengaruh terhadap biaya modal ekuitas pada perusahaan di indeks JII dan LQ 45 tidak terbukti kebenarannya.

d. Kualitas audit berpengaruh terhadap biaya modal ekuitas pada perusahaan di indeks JII. Sehingga hipotesis yang menyatakan bahwa kinerja perusahaan berpengaruh terhadap biaya modal ekuitas pada perusahaan di indeks JII terbukti kebenarannya. Sedangkan pada perusahaan LQ45 kualitas audit tidak berpengaruh terhadap biaya modal ekuitas. Sehingga hipotesis yang menyatakan bahwa kinerja perusahaan berpengaruh terhadap biaya modal ekuitas tidak terbukti kebenarannya.

e. Investment opportunity set berpenga-ruh terhadap biaya modal ekuitas pada perusahaan di indeks 
JII dan LQ 45. Sehingga hipotesis yang menyatakan bahwa investment opportunity set berpengaruh terhadap biaya modal ekuitas terbukti kebenarannya.

\section{Referensi}

[1] Ahmed et al. 2008. Audit Quality, Alternative Monitoring Mechanisms, and Cost of Capital: An Empirical Analysis. http://ssrn.com/abstract=1124082

[2] Ashidiqi, Mukhammad Lutfi. 2013. Pengaruh Manajemen Laba, Risiko Beta, dan Ukuran Perusahaam Terhadap Biaya Modal Ekuitas Perusahaan Manufaktur Yang Terdaftar Di Bursa Efek Indonesia Periode 2009-2011. Skripsi, Universitas Negri Yogyakarta, Yogyakarta.

[3] Brigham, Eugene F. Dan Weston J.F. 1994. Dasar Manajemen Keuangan. Jakarta: Erlangga

[4] Devani, Vera, dan Ade Setiawarnan. 2015. Pengukuran Kinerja Perusahaan dengan Manggunakan Metoda Balance Scorecard. Jurnal Sains Teknologi dan Industri, Vol. 13, No. 1.

[5] Esmaeili, Shima and Abbas Alimoradi Sharifabadi. 2015. Internal Control Weakness, Firm Performance, and Cost of Capital of the Companies Listed in Tehran Stock Exchange. International Journal of Management, Accounting \& Economics, Vol. 1, No. 1: 71-87.

[6] Fernando et al. 2008. Audit Quality Attrubutes, Client Size and Cost of Capital. http://ssrn.com/abstract=817286

[7] Fitriyani. 2014. Pengaruh Manajemen Laba Terhadap Biaya Modal Ekuitas (Pada Perusahaan Manufaktur yang Terdaftar di Bursa Efek Indonesia). Skripsi, Universitas Widyatama, Bandung.

[8] Ghozali, Imam. 2011. Aplikasi Analisis Multivariate Dengan Program IBM SPSS 19. Semarang: Badan Penerbit Universitas Diponegoro.

[9] Hajiha, Z. and Neda Sobhani. 2012. Audit Quality and Cost of Equity Capital: Evidence from Iran. International Research Journal of Finance and Economi, pp: 159-171
[10] Hermuningsih, Sri. 2012. Dampak Invesment Opportunity Set Terhadap Cost Of Equity Capital Dengan Diclosure Sebagai Variabel Mediasi. Doctoral Colloquium \& Conference FEB UGM.

[11] Nurjanati, Ratri dan Amad Rodoni. 2015. Pengaruh Asimetri Informasi dan Tingkat Disclosure Terhadap Biaya Ekuitas Dengan Kepemilikan Manajerial Sebagai Variabel Moderating (Studi Empiris Pada Perusahaan Manufaktur Di Bursa Efek Indonesia). Jurnal Bisnis dan Manajemen, Vol. 5, No. 2.

[12] Ifonie, Regina Reizky. 2012. Pengaruh Asimetri Informasi dan Manajemen Laba Terhadap Cost of Equity Capital Pada Perusahaan Real Estate Yang Terdaftar DI Bursa Efek Indonesia. Jurnal Ilmiah Mahasiswa Akuntansi, Vol. 1, No. 1.

[13] Kirana, Pangestika Ayu Aji. 2013. Pengaruh Kualitas Audit Terhadap Cost of Equity Capital (Studi Empirik pada Perusahaan yang Terdaftar di Bursa Efek Indonesia Tahun 2011). Skripsi, Univesitas Diponegoro, Semarang.

[14] Mulyadi. 2002. Auditing-Edisi Keenam Buku 1. Jakarta: Salemba Empat.

[15]Murni, Tri. 2002. Upaya Peningkatan Kualitas Perencanaan Pembangunan Melalui Pendekatan Manajemen Partisipatif di Kntor Bappeda Kabupaten Boyolali. Tesis, Universitas Muhammadiyah Surakarta, Surakarta.

[16] Myers, S. 1977. Determinants of Corporate Borrowing. Journal Financial Economics, Vol. 5:147-175.

[17] Norpratiwi, M.V. Agustina. 2004. Analisis Korelasi Investment Opportunity Set terhadap Return Saham. Universitas Gajah Mada: Yogyakarta.

[18] Pratiwi, Tri Kartika, dan Ferry Madi Ika Pratama. 2012. Pengaruh Kinerja Keuangan, Good Corporate Governance Terhadap Nilai Perusahaan Food and Beverage. Jurnal Manajemen dan Kewirausahaan, Vol. 14, No. 2.

[19]Rehman, Muhammad Teequr and Qamaruz Zaman. 2011. Does Corporate Performance Predict the Cost of Equity Capital?. American 
Journal of Social and Management Science, 26-33.

[20] Setiawan, Jonata Agus dan Daljono. 2014. Pengaruh Kualitas Audit Terhadap Manajemen Laba dan Biaya Modal Ekuitas. ISSN, Vol. 3, No. 1: 1-9.

[21] Suparno, Denny Prasetyo. 2013. Analisis Hubungan Antara Atribut Kualitas Audit Dengan Biaya Ekuitas Modal (Studi Empiris Pada Perusahaan Yang Terdaftar di Bursa Efek Indonesia 2009-2011). Skripsi, Univesitas Diponegoro, Semarang.

[22] Tjager, I.N., F.A. Alijoyo, H.R. Djemat, dan B. Sembodo. 2003. Corporate Governance: Tantangan dan Kesempatan bagi Komunitas Bisnis Indonesia. Pearson Education-Prentice Hall.

[23] Trisnawati, Rina dkk. 2016. Praktik Manajemen Laba Riil Pada Indeks JII dan LQ45 Bursa Efel Indonesia. ISSN, 2407-9189 [24]Utami, Wiwik. 2005. Pengaruh Manajemen Laba Terhadap Biaya Modal Ekuitas (Studi pada Perusahaan Publik Sektor Manufaktur. Jurnal SNA VIII, Solo. 